\title{
Changes in Diapause Related Gene Expression Pattern during Early Embryonic Development in HCl-treated Eggs of Bivoltine Silkworm Bombyx mori (Lepidoptera: Bombycidae)
}

\author{
Sirigineedi Sasibhushan, Kangayam M. Ponnuvel"and Nanjappa B. Vijayaprakash \\ Genomics Laboratory; Seribiotech Research Laboratory; Carmelaram Post, Kodathi, Bangalore 56003 - India
}

\begin{abstract}
Investigation of differential expression of diapause related genes (five metabolic, five heat shock protein and one translational regulatory) in $\mathrm{HCl}$-treated (non-diapause) and untreated (diapause) eggs of $\mathrm{B}$. mori during early embryogenesis (up to $48 \mathrm{~h}$ following oviposition) revealed the up-regulation of sorbitol dehydrogenase upon $\mathrm{HCl}$ treatment, indicating increased glycogen synthesis for further embryonic development but, down-regulation of phosphofructo kinase gene expression after $18 \mathrm{~h}$ of oviposition indicating an arrest of glycerol and sorbitol conversion. The expression of poly A binding protein gene expression was higher upon HCl treatment, revealing the initiation of translation. The expression levels of other genes analyzed did not vary significantly, except for Hsp 90 and Hsp40, which were up-regulated on acid treatment until 18h. Thus, Sorbitol dehydrogenase and phosphofructo kinase genes have a crucial role in diapause termination as evidenced by HCl treatment, while the other genes did not have major roles.
\end{abstract}

Key words: hibernation; acid treatment; metabolic genes; heat shock protein genes

\section{INTRODUCTION}

Diapause is an alternative developmental pathway with its own metabolic demands. In the insect lifecycle, it is accomplished by the dynamic change of developmental, behavioral and physiological events. Generally, diapause is influenced by the environmental factors such as temperature, humidity, light and nutrition. However, it is controlled by various genes which are expressed at different levels depending upon external stimuli (Saravanakumar and Ponnuvel 2007).

On initiation of diapause, metabolic activities are suppressed and the suppression facilitates the insect to extend its food reserves to bridge the hostile conditions. During diapause, survival is also enhanced by the synthesis of polyols and other cryoprotectants and several longivity classes of heat shock proteins. On termination of diapause metabolic rate rapidly increases, initiating the development hence, predictably genes involved in the metabolic suppression would be downregulated and those involved in the initiation would be up-regulated (Hahn and Denlinger 2007). The accommodation of the neurons in the brain during the embryonic development causes various morphological and morphometric changes and these changes can regulate the expression of different developmental genes. The different brain specific gene expression was studied during the post-embryonic development in ant Acroyrmex

*Author for correspondence: kmpvel@yahoo.com 
octospinosus, which showed similar features to those described for other insects (Soares et al. 2004).

In the silkworm Bombyx mori (L.) (Lepidoptera: Bombycidae), diapause is triggered by a neuropeptide diapause hormone $(\mathrm{DH})$, released from the neurosecretory cells of the subesophageal ganglion (SG), in the mother via corpora cardia corpora allata into the hemolymph, which then targets the developing ovaries (Yamashita 1996; Mitsumasu et al. 2008). Only eggs originating from the oocytes receiving the $\mathrm{DH}$ signal stage enter diapause at gastrula (Homma et al. 2006). Multiple genes are expressed during the induction, initiation and termination stages of diapause. There is a sufficient database available that describes the physiological features of diapause, its environmental regulation and the hormonal control mechanism (Hahn and Denlinger 2010). Robich et al. (2007) studied the molecular mechanism of diapause in Culex pipiens and identified 32 genes that were either up-regulated or down-regulated during the early, late or throughout dormancy. The embryonic development in $B$. mori is interesting because in certain races, embryonic development precedes uninterrupted (non-diapause), while in some, it is characterized by the diapause. The diapause eggs can be artificially treated with $\mathrm{HCl}$ to continue embryonic development without interruption. Therefore, silkworm eggs provide an ideal material for examining the adaptability of glycogen metabolism and its role in diapause (Chandrashekar and Bali 1987). Glycogen is stored in the eggs of the silkworm and is utilized as and when energy is required during the course of diapause as well as embryonic development (Chino 1958). The activation of glycogen phosphorylase (GPase) and glucose-6-phosphate dehydrogenase gene (G6PD) activity was assayed in the direction of glycogen breakdown. The absence of phosphofructokinase (PFK) and high activity of glucose-6-phosphate dehydrogenase gene (G6PD) gene suggests predominant pathway in carbohydrate metabolism in the early stages of embryogenesis (Kageyama and Ohnishi 1973). With the onset of embryonal diapause in silkworm, B. mori is accompanied by the conversion of glycogen into glycerol and sorbitol. The phosphofructokinase (PFK) acts as a primary enzyme playing a key role in the conversion. Diapause termination is followed by glycogen synthesis from these sugar alcohols, i.e., glycerol and sorbitol. The sorbitol is then converted to glycogen, which is a source of energy for embryogenesis. The conversion is controlled by the key enzyme NAD dependent sorbitol dehydrogenase-2(SDH-2) (Chino 1958). Trehalose is the sugar used for inter tissue transport of carbohydrate fuel in the insects and is typically made from glycogen reserves in the fat body and exported into the hemolymph for uptake and use by other tissues (Wyatt 1967). The gene expression of ovary trehalase (Tre) in the silkworm is induced by the diapause hormone (DH) (Ikeda et al. 1993; Su et al. 1994). The pivotal role in the insects is achieved by the action of key enzyme trehalase (Tre). The poly A binding protein (PABP) plays an important role in mRNA stabilization and translation. The storage of mRNAs in stress granules during hypometabolism is observed to be a useful mechanism to preserve the valuable pool of un-translated mRNAs until normal conditions are re-established. This provides a very rapid re-initiation of the translation of key transcripts to provide protein products that are needed immediately during arousal from the hypo metabolic state. The poly A binding protein (PABP) are prominent protein constituent of stress granules. Hahn and Denlinger (2010) observed that the expressions of PABP gene remained unchanged throughout the diapause period of $C x$. pipiens but was down-regulated in non-diapause mosquitoes. The orthologous sequence of this gene was retrieved from $B$. mori EST database to analyse the expression levels in diapausing and non-diapausing eggs of the silkworm B. mori.

Heat shock proteins (HSPs) represent a ubiquitous component of stress response in diverse organisms (Lindquist and Craig 1988), suggesting their role played in the rapid increase in stress tolerance during early diapause. The up-regulation of HSPs appears to be common in diapausing insects at different developmental stages (Storey and Storey 2004). The $\mathrm{HCl}$ treatment has been shown to be useful to prevent the entry into diapause or to break diapause and has made it possible to provide newly hatched $B$. mori larvae whenever farmers required to rear them (Andrewartha 1952). The treatment of newly laid bivoltine silkworm eggs with $\mathrm{HCl}$ breaks the diapause, forming nonhibernating eggs. The $\mathrm{HCl}$ treated eggs undergo developmental changes and hatch after nine days of incubation, while the non-treated eggs enter hibernation and hatch after four months 
preservation under $5^{\circ} \mathrm{C}$. As the onset of diapause occurs predominantly in the early stage, i.e., within $30 \mathrm{~h}$ of oviposition, it is worth analyzing the differential gene expression at this crucial period to find out the significant up- as well as downregulation of diapause related genes involved in non-diapause process. Earlier findings indicated that few metabolic and heat shock protein genes were differentially expressed during the onset of diapause (Saravanakumar et al. 2008; Ponnuvel et al. 2010). Based on the available information, an attempt has been made to investigate the molecular aspects of these major genes involved in diapause phenomenon in $\mathrm{HCl}$ treated (non-diapause) and untreated (diapause) eggs during early embryogenesis.

\section{MATERIALS AND METHODS}

\section{Strain selection and sample preparation}

The bivoltine silkworm strain CSR 2 (evolved by CSRandTI, Mysore) was selected for the study. The larvae of this strain were reared as per standard rearing methods (Krishnaswami 1978) and newly deposited disease-free eggs were collected for the study. To break the diapause and to obtain non-diapause bivoltine silkworm eggs, fifty disease-free bivoltine eggs were treated with $\mathrm{HCl}$ (specific gravity of 1.110 ) at $25^{\circ} \mathrm{C}$ for 90 min. After acid treatment, the eggs were thoroughly washed in running water to remove the traces of acid and air-dried.

\section{RNA isolation}

The diapause and $\mathrm{HCl}$ treated (non-diapause) egg samples were collected at $0 \mathrm{~h}$ and then after every $6 \mathrm{~h}$ up to $48 \mathrm{~h}$. Total RNA was extracted from the eggs using TRIzol reagent (Invitrogen) and quantified by measuring the UV absorbance at 260 or $280 \mathrm{~nm}$. The total RNA samples were denatured in formaldehyde, formamide and electrophoresed in $2.0 \%$ agarose gels.

\section{cDNA preparation}

The first strand cDNA was synthesized utilizing RNA $(2 \mu \mathrm{g})$ treated with $0.5 \mu \mathrm{l}$ of DNase buffer and $0.5 \mu \mathrm{l}$ of DNase (Invitrogen) for 15 minutes. Then, the reaction was terminated by heating at $75^{\circ} \mathrm{C}$ for 10 minutes and $1 \mu \mathrm{l} 10 \mathrm{mM}$ dNTP, oligo $(\mathrm{dT})_{18}$ (Eurofin India Pvt Ltd, Bangalore) was added, followed by incubation at $65^{\circ} \mathrm{C}$ for $5 \mathrm{~min}$. Finally, $1 \mathrm{X}$ reverse transcriptase buffer $(4 \mu \mathrm{l}), 5 \mathrm{mM}$ DTT
(1 $\mu \mathrm{l})$ and M-MLV Superscript III reverse transcriptase (Invitrogen) (1 $\mu \mathrm{l})$ was added to obtain a final volume of $20 \mu$ l. The reaction was terminated by heating at $75^{\circ} \mathrm{C}$ for $10 \mathrm{~min}$ according to the manufacturer's protocol.

\section{Identification of metabolic genes and primer design}

The B. mori Tre (Acc No. D13763) sequence was retrieved from the database and the forward (5'cgctgcttcattacgttcaa-3') and reverse (5'tgttcgggtttttcaaggac-3') primer were designed for cDNA sequence. Similarly, the $S D H-2$ gene cDNA sequence (Acc No. DQ443393) was retrieved and primers were designed for the cDNA sequence as forward (5'-gatggtagcgagtgggaaaa-3') and reverse $\left(5^{\prime}\right.$-gatagcccaagcaaggttca- $\left.3^{\prime}\right)$; and $P A B P$ gene (Acc No. NM_001098353) cDNA sequence was retrieved and primer designed as forward (5'- tggacgtgcacaaaagaaag- $\left.3^{\prime}\right)$ and reverse (5' - gagggagcgatggtacaaaa - 3'). However, as the sequences for the other genes like GPase, $P F K$ and G6P-DH were not reported in B. mori, the heterologus gene sequences available in Drosophila melanogaster and Antheraea paukstadtorum were retrieved and used for identification of homologous corresponding gene sequences in the Bombyx silk database. The $D$. melanogaster GPase gene was homology searched with the silk database (http://morus.ab.a.utokyo.ac.jp) and the sequence (Acc No.NRPG1576), which showed the maximum homology with the Bombyx GPase gene was selected. Based on the gene sequence, the forward (5'-gatggtgatcgagaacatcg-3') and reverse (5'caagctgcgagtttaaagtacaa-3') primers were designed. Similarly, $P F K$ gene cDNA sequence (Acc No. ovS302A08f) retrieved from the silk database formed the basis for designing the PFK forward (5'-atgaactccatgcacctagc-3') and reverse (5'-caatatttgattaccacgatgga-3') primers. The $A$. paukstadtorum G6P-DH gene was also searched in silk database and the gene sequence (Acc No. fcaL-P16_F_O12) which showed homology with Bombyx G6P-DH was retrieved. Subsequently, the forward (5'-aacctttgccgcataacac-3') and reverse (5'- gctgacatcatcacgtccaa-3') primers were designed for the $G 6 P-D H$ gene sequence.

\section{Identification of heat shock protein genes and primer design}

The heat shock protein genes were analyzed for diapause and $\mathrm{HCl}$ treated eggs. The B. mori Hsp 
20.4 gene sequence was obtained from the database (Acc No. AF315318) and forward (5'tttggecttgccttaacac-3') and reverse (5'ttcgctctggtccttgatct-3') primers were designed. Hsp 20.8 gene sequence (Acc No. AF315317) was also searched from the database and forward (5'ctaacccegaacgacatgct-3') and reverse (5'gatgtacccatcggcagtct-3') primers were designed. Similarly, Hsp 40 gene sequence (Acc No. AB206400) and $h s p 70$ (Acc No. DQ311189.1) gene sequences were obtained and forward (5'tcggacgatgacatcaagaa- $\left.3^{\prime}\right)$ and reverse (5'cccgggcgatatcttctaat-3') primers for $H s p 40$ and forward (5' - gaacacactcgctgcacatc-3') and reverse (5'-gaggagtgcccaagatcgac-3') primers for $h s p 70$ were designed. Based on Hsp 90 cDNA (Acc.No.AB060275) sequence, the requisite forward (5'-ttcccagttcattggctacc-3') and reverse (5'-tcttgcgcttcttgttttca-3') primers were designed.

\section{Reverse transcription polymerase chain reaction ( $R T$ pcr) analysis}

The PCR amplification was performed in a $25 \mu \mathrm{l}$ reaction mixture containing $2.0 \mu \mathrm{l} 10 \mathrm{X}$ reaction buffer (100mM Tris-HCL, pH 8.3, 500mM KCl), $0.2 \mathrm{mM}$ dNTPs, $1.5 \mathrm{mM} \mathrm{MgCl} 2,10$ picomoles of forward and reverse primers, $0.3 \mathrm{U}$ of Taq DNA polymerase (MBI Fermentas) with $1 \mu \mathrm{l}$ first strand cDNA as template. $\beta$ actin (FP 5' cactgaggetccctgaac 3' and RP 5' ggagtgcgtatccctcgtag 3') (Bangalore Genei) was used as an internal standard. The PCR amplification was carried out under the following conditions: $94^{\circ} \mathrm{C}$ for 3 min followed by 27 cycles of $94^{\circ} \mathrm{C}$ for $30 \mathrm{~s}, 50^{\circ} \mathrm{C}$ for $30 \mathrm{~s}, 72^{\circ} \mathrm{C}$ for $2 \mathrm{~min}$ and a final extension of $7 \mathrm{~min}$ at $72^{\circ} \mathrm{C}$.

\section{Semi-quantitative measurement}

The semi-quantitative reverse transcriptasepolymerase chain reaction (RT-PCR) method was adopted according to Goto and Kimura (2004) for the quantification of mRNA. In this experiment, PCR reactions with 30 cycles were fixed for metabolic genes, $H s p$ genes and $\beta$ actin. After PCR, gel electrophoresis was carried out wherein equal volumes of the PCR product of each sample were run in triplicate on a $1.5 \%$ agarose gel. The PCR products were detected under UV after staining with ethidium bromide; the intensity of stained products quantified by a Densito quantifying image analyzer (Syngene Gel documentation system, Madison, USA) and mean values were calculated. The RT-PCR was performed in Pectoralis major muscle cDNA samples isolated from the meats of two phenotypically distinct chicken lines to investigate the $\alpha$-ryr and $\beta$-ryr gene expression by real-time RT-PCR approach using $\beta$ actin gene as internal standard (Oda et al. 2009). The $\beta$-actin gene of $B$. mori was used as an internal control to normalize the gene expression in diapause and non-diapause eggs.

\section{RESULTS}

\section{Metabolic enzyme and translational regulatory gene expression}

The expression of metabolic enzyme genes, viz., phosphofructo kinase (PFK), sorbitol dehydrogenase (SDH-2), trehalase (Tre), glycogen phosphorylase (GPase), glucose-6-phosphate dehydrogenase (G6PD) and poly A binding protein (PABP) involved during early embryogenesis (6 to $48 \mathrm{~h}$ after oviposition) were analyzed in diapause and non-diapause $(\mathrm{HCl}$ treated) eggs of the bivoltine silkworm B. mori (Fig. 1).

\section{Phosphofructo kinase gene (PFK)}

The present study revealed that phosphofructo kinase (PFK) expression levels were similar up to $18 \mathrm{~h}$ in both type of eggs. However, the diapause eggs revealed a higher trend compared to the $\mathrm{HCl}$ treated (non-diapause) eggs that continued until 48 h. In the $\mathrm{HCl}$ treated (non-diapause) eggs PFK expression sharply declined from 18 to $24 \mathrm{~h}$ with no further expression until $48 \mathrm{~h}$.

\section{Sorbitol dehydrogenase gene (SDH)}

The SDH gene did not reveal much expression until $48 \mathrm{~h}$ in diapause eggs. In the $\mathrm{HCl}$ treated (non-diapause) eggs, the gene expression level was similar to diapause eggs until $6 \mathrm{~h}$ and then increased sharply at $12 \mathrm{~h}$ to reach a maximum at $18 \mathrm{~h}$. This was followed by a sharp decline until 30 $\mathrm{h}$ with a sharp increase at $36 \mathrm{~h}$. No expression was observed at 42 and $48 \mathrm{~h}$. 


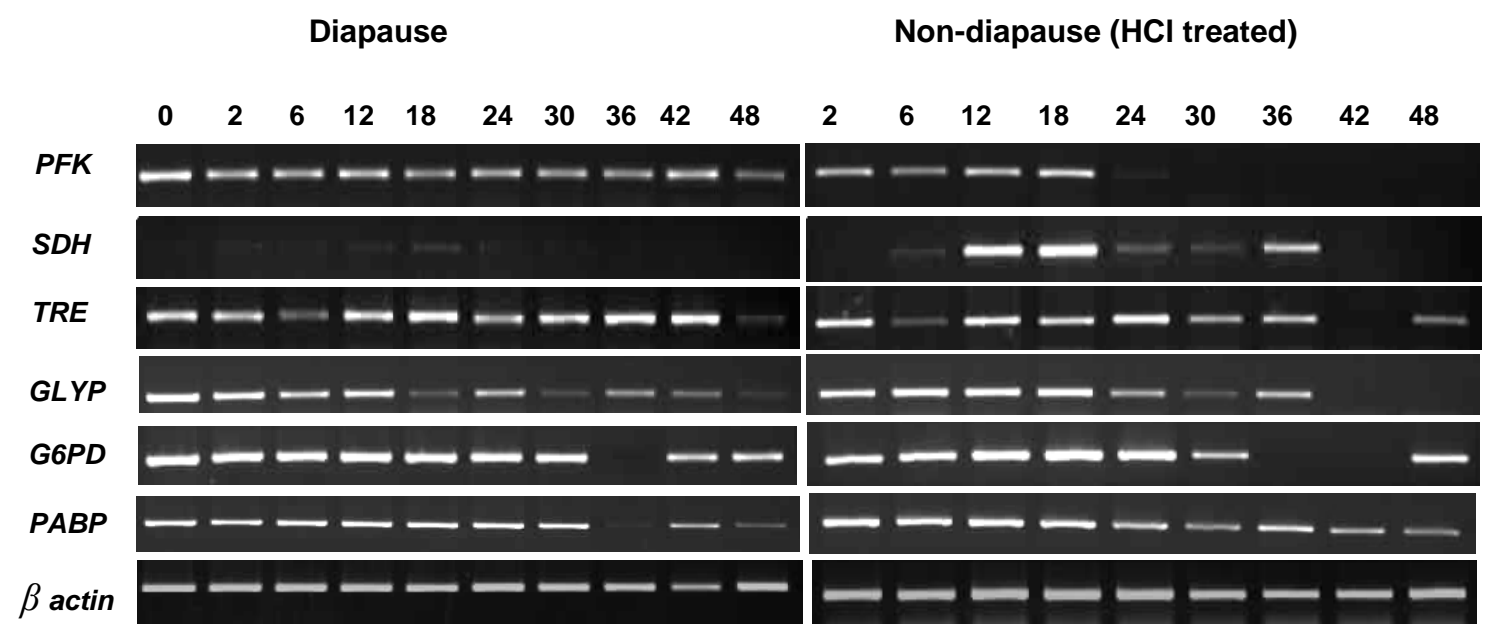

Figure1 - Metabolic gene and translational regulatory gene expression patterns in diapause and $\mathrm{HCl}$ treated (non-diapause) eggs of silkworm Bombyx mori. The RNA from diapause and $\mathrm{HCl}$ treated (non-diapause) induced eggs was isolated at 6 hourly intervals from 0 to $48 \mathrm{~h}$ after oviposition and the gene products were run on $1.5 \%$ agarose gel. $\beta$ actin was used as internal standard to confirm equal loading. Each sample was run in triplicate.

\section{Trehalase gene (Tre)}

Tre expression levels in the diapause and nondiapause eggs were similar until $12 \mathrm{~h}$. However, in the diapause eggs, the expression levels slightly increased at $18 \mathrm{~h}$ but dropped at $24 \mathrm{~h}$ with a gradual increase until $42 \mathrm{~h}$ and decrease at $48 \mathrm{~h}$. In the $\mathrm{HCl}$ treated eggs, the gene expression fluctuated from $12 \mathrm{~h}$ to $48 \mathrm{~h}$.

\section{Glycogen phosphorylase (GPase)}

GPase expression in the diapause eggs declined until $18 \mathrm{~h}$ and fluctuated till $36 \mathrm{~h}$, followed by the gradual decrease till $48 \mathrm{~h}$. The expression levels of the $\mathrm{HCl}$ treated (non-diapause) eggs did not change from 6 to $18 \mathrm{~h}$ but were at a level higher than that of the diapause eggs. The GPase expression gradually decreased till $30 \mathrm{~h}$ to sharply increase by $36 \mathrm{~h}$, followed by sharp decrease at 42 h. No expression was observed at 42 and $48 \mathrm{~h}$.

\section{Glucose- 6-phosphate dehydrogenase gene (G6PD)}

The G6PD gene expression in the diapause eggs revealed a gradual decline till $30 \mathrm{~h}$ with no expression at $36 \mathrm{~h}$. However, the expression levels increased from 36 to $48 \mathrm{~h}$. In the $\mathrm{HCl}$ treated (nondiapause) eggs, the expression pattern increased until $18 \mathrm{~h}$ and later declined until $36 \mathrm{~h}$. In general, similar expression pattern was observed in both the eggs.

\section{Poly A binding protein gene (PABP)}

The PABP gene expression also was stable in the diapause eggs until $30 \mathrm{~h}$, but declined to undetectable levels at $36 \mathrm{~h}$, rose sharply at $42 \mathrm{~h}$ and further declined by 48 . In contrast, the expression levels in the $\mathrm{HCl}$ treated (nondiapause) eggs gradually declined till $30 \mathrm{~h}$. Later, it increased sharply up to $36 \mathrm{~h}$ followed by gradual decline till $48 \mathrm{~h}$.

\section{Heat shock protein (Hsp) expression}

Like the metabolic enzyme genes, the heat shock protein genes were also analyzed after every $6 \mathrm{~h}$ following the oviposition up to $48 \mathrm{~h}$ in the diapause and $\mathrm{HCl}$ treated (non-diapause) eggs (Fig. 2).

\section{Hsp 20.4}

The Hsp 20.4 gene expression levels in the diapause eggs declined till $6 \mathrm{~h}$ and slightly increased till $18 \mathrm{~h}$. Later, it steadily decreased up to $24 \mathrm{~h}$, followed by no expression from $30 \mathrm{~h}$ till 48 h. The $\mathrm{HCl}$ treated (non-diapause) eggs revealed a decreasing pattern till $30 \mathrm{~h}$, except for a slight increase at 6 and $24 \mathrm{~h}$ respectively. However, expression was observed from $30 \mathrm{~h}$ till $42 \mathrm{~h}$ with nil expression by $48 \mathrm{~h}$. 


\section{Hsp 20.8}

The expression levels of Hsp 20.8 revealed a similar pattern in both the type of eggs till $12 \mathrm{~h}$. Later, both the eggs revealed a fluctuating expression up to $48 \mathrm{~h}$.

\section{Hsp 40}

The Hsp 40 expression levels in the diapause eggs revealed a decreasing pattern till $30 \mathrm{~h}$, with a sharp dip at $6 \mathrm{~h}$ and sharp rise at 12h. Later, the expression levels increased to some extent by $36 \mathrm{~h}$ to decline to nil by $48 \mathrm{~h}$. The $\mathrm{HCl}$ treated (nondiapause) eggs revealed an increasing pattern and recorded a peak level expression at $18 \mathrm{~h}$, which declined sharply till $30 \mathrm{~h}$, followed by sharp rise at $36 \mathrm{~h}$ and fall by $42-48 \mathrm{~h}$.

\section{Hsp 70}

The Hsp 70 gene expression varied greatly in the diapause eggs and the expression levels decreased sharply up to $6 \mathrm{~h}$, followed by sharp increase up to
$24 \mathrm{~h}$, which recorded a peak expression. This was followed by sharp decline by $30 \mathrm{~h}$ and a slight rise and fall till $48 \mathrm{~h}$. The overall expression of $\mathrm{HCl}$ treated (non-diapause) eggs revealed a decreasing pattern till $48 \mathrm{~h}$.

\section{Hsp 90}

The Hsp 90 gene expression levels in general increased up to $18 \mathrm{~h}$ with no expression recorded at $30 \mathrm{~h}$ in both the cases but at a higher level in $\mathrm{HCl}$ trated (non-diapause) eggs. However, in the diapause eggs, there was a slight decrease from 0 to $6 \mathrm{~h}$, which later increased up to $18 \mathrm{~h}$, followed by a dip till $30 \mathrm{~h}$. A low level of expression was observed at $36 \mathrm{~h}$, which gradually decreased till 48 h. In the $\mathrm{HCl}$ (non-diapause) treated eggs, a gradual rise was observed from 0 to $18 \mathrm{~h}$, followed by a sharp dip at $24-30 \mathrm{~h}$. This was followed by a sharp rise up to $36 \mathrm{~h}$, a sharp decline up to $42 \mathrm{~h}$ and then a slight increase till $48 \mathrm{~h}$.

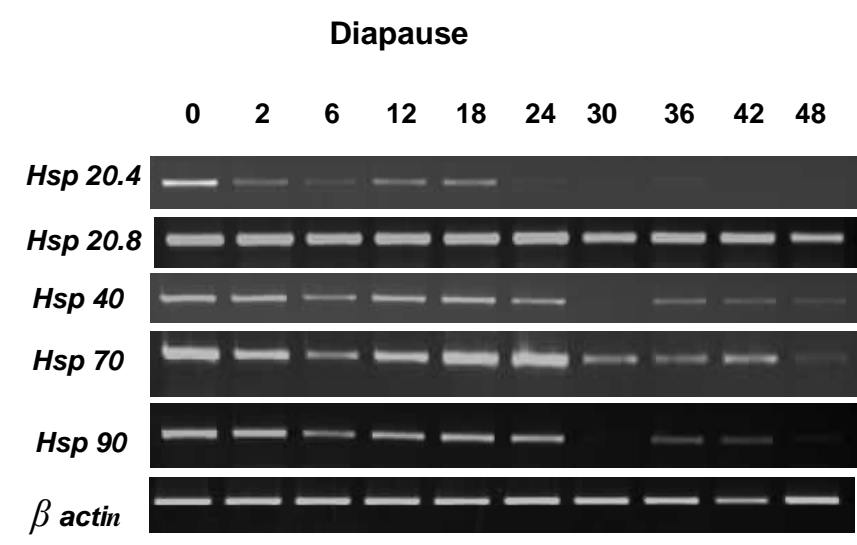

Non-diapause $(\mathrm{HCl}$ treated)

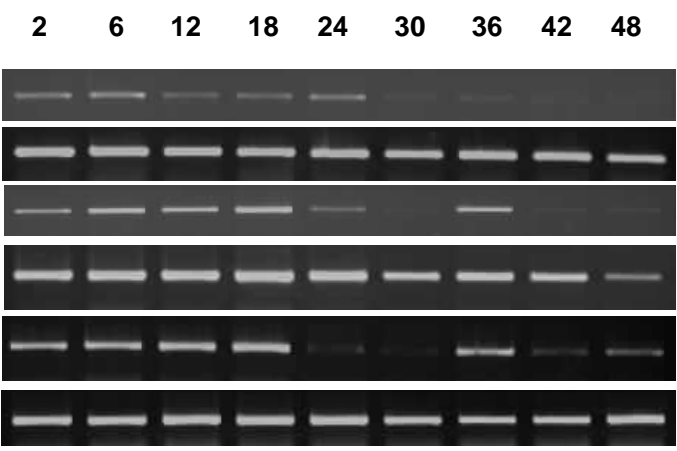

Figure 2 - Heat shock protein gene expression patterns in diapause and non $\mathrm{HCl}$ treated (nondiapause) eggs of silkworm Bombyx mori. The RNA from diapause and $\mathrm{HCl}$ treated (nondiapause) induced eggs was isolated at 6 hourly intervals from 0 to $48 \mathrm{~h}$ after oviposition and the gene products were run on $1.5 \%$ agarose gel. $\beta$ actin was used as internal standard to confirm equal loading. Each sample was run in triplicate.

\section{DISCUSSION}

The silkworm B. mori follows a system of hibernation adopted by insects during their life cycle (Andrewartha 1952). Only eggs originating from the oocytes that receive the DH signal enter the diapause at the gastrula stage (Homma et al. 2006). The bivoltine silkworm eggs enter diapause and hatch after four months preservation under $5^{\circ}$
C. Alternatively, the diapause can be broken by treating the eggs with $\mathrm{HCl}$ immediately after oviposition. Reports have indicated that Tre, GPase, G6PD and SDH genes expressed at different levels in various target tissues of $B$. mori are actively involved in the diapause process and in the eggs, diapausing is completed by $24-36 \mathrm{~h}$ (Sakano et al. 2004; Saravanakumar et al. 2008; Ponnuvel et al. 2010). The present study is an 
analysis of the expression of selected metabolic enzymes, translational regulatory gene and HSP genes within $48 \mathrm{~h}$ of oviposition in both the diapause and $\mathrm{HCl}$ treated (non-diapause) bivoltine silkworm eggs.

\section{Metabolic enzyme genes and translational regulatory gene expression}

The onset of embryonic diapause in the silkworm, B. mori, is accompanied by the conversion of glycogen into glycerol and sorbitol with PFK playing a key role in the conversion. The higher trend of PFK gene expression in the diapause eggs compared to $\mathrm{HCl}$ treated (non-diapause) eggs in the present study confirmed the PFK role in conversion. In freeze tolerant goldenrod gall fly (Eurosta solidaginis), glycerol is utilized in the pentose phosphate pathway. However, when the temperature drops below $5^{\circ} \mathrm{C}$, PFK expression is strongly inhibited, diverting the metabolism from glycerol to sorbitol synthesis (Storey and Storey 1983; Tsumuki et al. 1987). Less expression of the PFK gene in the $\mathrm{HCl}$ treated (non-diapause) eggs from 24 to $48 \mathrm{~h}$ indicated the probable enzyme inactivation via protein phosphorylation during the early embryogenesis.

Diapause termination is followed by glycogen synthesis from glycerol and sorbitol, which is controlled by the NAD - sorbitol dehydrogenase (SDH) (Yaginuma and Yamashita 1979). The present study also revealed nil expression of the gene from 0 to $48 \mathrm{~h}$ in the diapause eggs. In the eggs treated with $\mathrm{HCl}$, the SDH activity increased rapidly (Yaginuma et al. 1990). Similar type of SDH gene expression pattern, i.e., higher level of expression from 6 to $18 \mathrm{~h}$, was observed in the $\mathrm{HCl}$ treated (non-diapause) eggs suggesting that SDH was a key enzyme for sorbitol degradation at the termination of diapause in B. mori eggs.

Glycogen phosphorylase (GPase) is activated by anaerobic condition in diapause and non-diapause eggs (Yamashita et al. 1975). In the present study also, both the diapause and $\mathrm{HCl}$ treated (nondiapause) eggs revealed equivalent GPase gene expression at a high level, indicating similar glycogen requirement in both the types of eggs.

In an earlier study, it was observed that G6PD activity was maintained at a high level throughout the diapause and embryonic development that dropped suddenly before the hatching (Suzuki and Miya 1975; Horie et al. 2000). The present results revealed the same high expression levels of G6PD up to $30 \mathrm{~h}$, except for a sharp decline at $36 \mathrm{~h}$ and the expression levels increased by $48 \mathrm{~h}$.

Trehalase (Tre) is distributed in almost all the tissues and organs of insects in different forms at various levels throughout the life cycle (Chen et al. 2010). Predominance of Tre gene was reported in the midgut throughout larval, pupal as well as adult development and far less in other tissues $(\mathrm{Su}$ et al. 1993; 1994). In the present study, higher expression level of Tre gene was observed after 12 $\mathrm{h}$ in the diapausing eggs, while, in the $\mathrm{HCl}$ treated (non-diapausing) eggs, the level increased up to 48 $\mathrm{h}$ after a sharp decline at $42 \mathrm{~h}$. This indicated that the Tre gene was selectively up-regulated during the early diapause (within $48 \mathrm{~h}$ of oviposition) as considerable energy was required during the early onset of diapause, for which trehalose was used as an energy source.

Hahn and Denlinger (2010) extensively reviewed the molecular events involved in the egg, pupal and adult diapause and observed that many genes were shutdown during the diapause while a small group of genes were up-regulated. Several classes of genes up-regulated as well as down-regulated in the diapause have been identified using suppresive substractive hybridisation ( $\mathrm{SSH}$ ) and microarray (Xia et al. 2007). Robich et al. (2007) identified 32 diapause related genes, which were specifically expressed during dormancy in Culex pipiens. Among these, the expressions of PABP gene remained unchanged throughout the diapause period of $C$. pipiens. However, PABP gene was down-regulated in non-diapause mosquitoes. It is also reported that PABP gene is involved in stage specific regulation in eukaryotic system (Storey and Storey 2004). In the present study the comparatively higher expression of $P A B P$ gene observed in non-diapause eggs indicated that these eggs might tend to produce more transcripts for its embryonic development and at higher concentration, PABP might regulate the early embryonic development. Since limited mRNA transcripts were present in the diapause eggs, the $\mathrm{PABP}$ requirement was also lower in the diapause eggs.

\section{Heat shock protein (Hsp) expression}

Although the molecular regulation of diapause remains largely unknown, there are many research findings suggesting the involvement of heat-shock proteins in the expression of diapause or dormancy (Rinehart 2007). Hsps are normally expressed in response to stress, acting as the molecular 
chaperones to prevent the abnormal folding of proteins. Generally, the Hsps are ubiquitously expressed in all the stages of embryo development (Sonodo et al. 2006). The present study revealed no significant variation in Hsp expression, except for Hsp 90 and Hsp 40, which showed maximum expressions up to $18 \mathrm{~h}$ after the oviposition in both the diapause and $\mathrm{HCl}$ treated (non-diapause) eggs. However, Hsp 20.4 expression was low in both the diapause and $\mathrm{HCl}$ treated (non-diapause) eggs, while the Hsp 20.8 expression did not vary much even though it fluctuated. In B. mori, Hsp 70 is synthesized in the diapausing and non-diapausing egg development at the early germ - anlage stage (Coulon and Dorel 1991; Rinehart et al. 2000) and also after the heat shock or acid treatment during the embryogenesis, except for two unaffected phases, namely the pre-blastodermic and deep diapause stages. The synthesis of Hsp70 could be induced again immediately by the end of the reactivation phase at $5^{\circ} \mathrm{C}$ for 35 days (Coulon and Mathelin, 1991). The present study revealed that the Hsp 70 gene expression was lower in the diapause eggs compared to non-diapause eggs during the rest of the hours, except for an increase during 18 to $24 \mathrm{~h}$.

Studies in Drosophila triauraria and the blow fly Lucilia silicate indicated no evidence of Hsp90 involvement in the diapause (Goto and Kimura, 2004). In contrast to this, in S. crassipalpis Hsp90 transcripts were down-regulated during the diapause (Rinehart and Denlinger, 2000). In flesh flies, the Hsp90 was up-regulated in response to cold shock (Joplin, 1990) but not involved in the diapause (Rinehart and Denlinger 2000). The present results revealed that the Hsp 90 gene expression was up regulated in $\mathrm{HCl}$ treated (nondiapause) eggs compared to the diapause eggs, indicating a significant role for Hsp 90 in early embryonic development of $\mathrm{HCl}$ treated (nondiapause) B. mori eggs.

The results of this study, thus, gave an insight into the molecular underpinnings involved in the process of diapause, which offered new tools that might prove valuable for developing the biomarkers to monitor the developmental status of various pests. Further studies on stage-specific protein profiles or mRNA expression patterns could prove useful for predicting the timing of diapause and its termination in most insect species in the field. This may also provide a unique opportunity to investigate the conserved regulatory mechanisms that sequentially halt and reinitiate the development as well as to understand the molecular basis of insect seasonality and other related topics.

\section{ACKNOWLEDGEMENTS}

This research work was supported by grants from Department of Biotechnology, Ministry of Science and Technology, Government of India (BT/PR11397/PBD/19/192/2008 dated 30th June 2009).

\section{REFERENCES}

Andrewartha HG. Diapause in relation to the ecology of insects. Biol Rev Camb Philos Soc. 1952; 27: 50-107.

Chino H. Carbohydrate metabolism in the diapause egg of the silkworm, Bombyx mori - II: Conversion of glycogen into sorbitol and glycerol during diapauses. J Insect Physiol. 1958; 2(1): 5-12.

Chandrashekar PM, Bali G. Glycogen level and glycogen phosphorylase activity in the eggs of silkworm, Bombyx mori. Proc Indian Acad Sci. Section B. 1987; 96(1): 49-54.

Chippendale GM. Hormonal regulation of larval diapause. Annu Rev Entomol. 1977; 22: 121-138.

Coulon M, Dorel C. The arrest of embryogenesis at gastrula stage in the diapausing silkworm Bombyx mori is related to the synthesis of protein p61. Dev Gene Evol. 1991; 199: 469-475.

Coulon M, Mathelin J. Variations in the rates of synthesis of heat shock proteins, Hsp70, between laying and neurula in the diapausing embryo of the silkworm, Bombyx mori. Sericologia. 1991; 31: 295300.

Goto SG, Kimura MT. Heat-shock-responsive genes are not involved in the adult diapause of Drosophila triauraria. Gene. 2004; 326: 117-122.

Hahn DA, Denlinger DL. Meeting the energetic demands of insect diapause: Nutrient storage and utilization. J Insect Physiol. 2010; 53: 760-773.

Homma T, Watanabe K, Tsurumaru S, Kataokab H, Imai $\mathrm{K}$, Kamba $\mathrm{M}$, et al. $\mathrm{G}$ protein-coupled receptor for diapause hormone, an inducer of Bombyx embryonic diapause. Biochem Bioph Res Co. 2006; 344: 386-393.

Horie Y, Kanda T, Mochida Y. Sorbitol as an arrester of embryonic development in diapausing eggs of the silkworm, Bombyx mori. J Insect Physiol. 2000; 46: 1009-1016. 
Ikeda K, Okazaki R, Inoue D, Ogata E, Matsumoto T. Transcription of the gene for parathyroid hormonerelated peptide from the human is activated through a cAMP-dependent pathway by prostaglandin E1 in HTLV-I-infected T cells. J Biol Chem. 1993; 268(2): 1174-1179.

Joplin KH, Yocum GD, Denlinger DL. Cold shock elicits expression of the heat shock protein in the flesh fly Sarcophaga crassipalpis. J Insect Physiol. 1990; 36: 825-834.

Kageyama T, Ohnishi E. Carbohydrate metabolism in the eggs of the silkworm, Bombyx mori. Dev. Growth Differ. 2003; 15(1): 47-55.

Kawasaki H, Sugaya K, Quan GX, Nohata J, Mita K. Analysis of a- and b-tubulin genes of Bombyx mori using an EST database. Insect Biochem Molec Biol. 2003; 33: 131-137.

Krishnaswami S. New technology of silkworm rearing. CSRTI, Mysore, 1978; Bulletin No. 2: 1- 24.

Lindquist S, Craig EA. The heat-shock proteins. Annu Rev Genet. 1988; 22: 631-677.

Mitsumasu K, Niimi T, Yamashita O, Yaginuma T. Diapause Hormone-enhanced Expression of the trehalase-2 Gene Encoding a Novel Membranepenetrating Type in Bombyx Developing Ovaries and the Gene Structure. J Insect Biotechnol Sericology. 2008; 75: 71-77.

Nakagaki M, Takei R, Nagashima E, Yaginuma T. Cell cycles in embryos of the silkworm, Bombyx mori: G2 arrest at diapause stage. Dev Genes Evol. 1991; 200: 223-229.

Oda SHI, Nepomuceno AL, Ledur MC, Oliveira MCN, Marin SRR, Ida EI, et al. Quantitative differential expression of alpha and beta ryanodine receptor genes in PSE (Pale, Soft, Exudative) meat from two chicken lines: broiler and layer. Braz Arch Biol Technol. 2009; 52: 1519-1525.

Ponnuvel KM, Geetha NM, Awasthi AK, Rao GP, Vijayaprakash NB. Diffrential gene expression during early embryonic development in diapauses and non diapause eggs of multivoltine silkworm Bombyx mori. Indian J Exp Biol. 2010; 48: 1143-1151.

Rinehart JP, Yocum GD, Denlinger DL. Developmental up regulation of inducible $H s p 70$ transcripts, but not the cognate form, during pupal diapause in the flesh fly, Sarcophaga carssipalpis. Insect Biochem Molec Biol. 2000; 30: 515-521.

Rinehart JP, Denlinger DL. Heat shock protein 90 is down regulated during pupal diapause in the flesh fly, Sarcophaga crassipalpis, but remains responsible to thermal stress. Insect Mol Biol. 2000; 9: 641-645.

Robich RM, Rinehart JP, Kitchen LJ, Denlinger DL. Diapause-specific gene expression in the northern house mosquito, Culex pipiens identified by suppressive subtractive hybridization. $J$ Insect Physiol. 2007; 53(3): 235-245.
Sakano D, Furusawa T, Sugimura Y, Storey JM, Storey KB. Metabolic shifts in carbohydrate metabolism during embryonic development of non-diapause eggs of the silkworm, Bombyx mori. J Insect Biotechnol Sericology 2004; 73: 15-22.

Saravanakumar R, Ponnuvel KM, Qadri SMH. Expression of metabolic enzyme genes and heat shock protein genes during embryonic development in diapause and non-diapause egg of multivoltine silkworm Bombyx mori. Biolgia. 2008; 63: 737-744.

Shanavas A, Arif A, Murthy CRK, DuttaGupta A. Developmental and hormonal regulation of actin and tubulin in the central nervous system of silkworm, Bombyx mori during postembryonic development. Curr Sci. 2004; 87(3), 83-87.

Soares PAO, Delabie JHC, Serrao JE. Neuropile organization in the brain of Acromyrmex (Hymenoptera, Formicidae) during the postembryonic development. Braz Arch Biol Technol. 2004; 47: 4.

Steele JE. The role of carbohydrate metabolism in physiological function. In: Energy Metabolism in Insects, ed. R.G.H. Downer., New York: Plenum Press 1981. p. 101-133.

Storey JM, Storey KB. Regulation of cryoprotectant metabolism in the over wintering gall fly larva, Eurosta solidaginis, temperature control of sorbitol and glycerol levels. J Comp Physiol. 1983; 149: 495502.

Storey KB, Storey JM. Metabolic rate depression in animals: transcriptional and translational controls. $Q$ Rev Biol. 2004; 79: 207-233.

Su ZH, Sato Y. Yamashita O. Purification, cDNA cloning and Northern blot analysis of trehalase of pupal midgut of the silkworm, Bombyx mori. Biochim Biophys Acta., 1993; 1173: 217-224.

Su ZH, Ikeda M, Sato Y, Imai K, Isobe M, Yamashita O. Molecular characterization of ovary trehalase of the silkworm, Bombyx mori and its transcriptional activation by diapause hormone. Biochim Biophys Acta. 1994; 1218: 366-374.

Suzuki K, Miya K. Studies on Carbohydrate metabolism in diapause eggs of the silkworm, Bombyx mori, with special reference to phosphofructokinase activity. J Seric Sci Jpn. 1975; 44(2): $88-97$.

Sonoda S, Fukumoto K, Izumi Y, Ashfaq M, Yoshida $\mathrm{H}$, Tsumaki HA. Small Hsp gene is not responsible for diapause and cold tolerance acquisition in Chilo suppressalis. J Appl Entomol. 2006; 130: 309-313.

Takashi K, Ohnishi E. Carbohydrate metabolism in the eggs of the Silkworm, Bombyx mori. Dev Growth Differ. 1973; 15(1): 47-55.

Tsumuki H, Rojas RR, Storey KB, Baust JG. The fate of (14C) glucose during cold hardening in Eurosta solidiaginis (Fitch). Insect Biochem. 1987; 17: 347352. 
Wyatt GR. The biochemistry of sugars and polysachharides in insects. In: Advances in Insect Physiology. New York: Academic Press; 1967. Vol 4. p. 287-360.

Xia Q, Cheng D, Duan J, Wang G, Cheng T, Zha X, et al. Microarray-based gene expression profiles in multiple tissues of the domesticated silkworm, Bombyx mori. Genome Biol. 2007; 8(8): R162.

Yaginuma T, Kobayashia M, Yamashita O. Effect of low temperature on NAD sorbitol dehydrogenase activity and morphogenesis in non-diapause eggs of the silkworm, Bombyx mori. Comp Biochem Physiol B. 1990; 97(3): 495-506.
Yamashita O. Diapause Hormone of the silkworm, Bombyx mori: structure, Gene expression and function. J Insect Physiol. 1996; 42: 669-679.

Yamashita O, Suzuki K, Hasegawa K. Glycogen phosphorylase activity in relation to diapause initiation in Bombyx egg. Insect Biochem. 1975; 5: 707-718.

Received: July 11, 2011; Revised: January 18, 2012; Accepted: August 09, 2012. 